Amanda Gabrielle Santos Leite O- https://orcid.org/0000-0001-5851-0642

Liz Freitas de Sá Oliveira'

Onttps://orcid.org/0000-0002-6706-5541

Ricardo Coutinho Fortes'

(1) https://orcid.org/0000-0002-2332-3107

Isa Menezes Lyra'

(1) https://orcid.org/0000-0003-1795-2588

\section{Prevalence of clinical manifestations suggestive of depression in patients with sickle cell disease: a review}

Prevalência de manifestações clínicas sugestivas de depressão em

pacientes portadores de doença falciforme: uma revisão

DOI: $10.1590 / 0047-2085000000366$

\begin{abstract}
Objective: To assess the prevalence of clinical manifestations suggestive of depression in patients with sickle cell disease. Methods: A systematic search was performed in the electronic databases PubMed", LILACS and SciELO, with the following inclusion criteria: cross-sectional studies that assessed the prevalence of depression in patients with sickle cell disease, published in English or Portuguese in the last 10 years. The selection of the articles was performed in two stages by two independent researchers following the PRISMA (Preferred reporting items for systematic reviews and meta-analyses) recommendations. The first stage consisted on screening the titles and abstracts, and in the second stage the full text was appraised, both following the pre-defined inclusion and exclusion criteria. Results: From the 42 articles available, nine were included in this review. Seven instruments were used to screen for depression with different cutoff points, and the Patient Health Questionnaire-9 (PHQ-9) was the most used instrument. The worldwide prevalence of clinical manifestations suggestive of depression ranged from 11 to 40\%, according to several variables. Conclusion: The prevalence of clinical manifestations suggestive of depression in patients with sickle cell disease is higher compared to the prevalence of depression in the general population. Thus, the multidisciplinary follow-up for these people, with a focus on mental health, is of great importance.
\end{abstract}

\section{KEYWORDS}

Sickle cell disease, depression, prevalence, major depressive disorder.

\section{RESUMO}

Objetivo: Avaliar a prevalência mundial de manifestações clínicas sugestivas de depressão em portadores de doença falciforme. Métodos: Realizou-se uma busca sistemática nas bases de dados eletrônicas PubMed", LILACS e SciELO, para identificação dos estudos transversais, publicados em inglês ou português nos últimos 10 anos, que avaliaram a prevalência de depressão em portadores de doença falciforme. A seleção dos artigos foi realizada em duas etapas e por dois pesquisadores independentes seguindo a recomendação PRISMA (Preferred reporting items for systematic reviews and meta-analyses). A primeira etapa consistiu na triagem dos títulos e resumos e na segunda etapa foi realizada a análise completa do artigo, ambas seguindo os critérios de inclusão e exclusão predefinidos. Resultados: Dos 42 artigos disponíveis, nove foram incluídos na revisão. Foram utilizados sete instrumentos diferentes para rastreio de depressão com diferentes pontos de corte, sendo The Patient Health Questionnaire-9 (PHQ-9) o instrumento mais utilizado. A prevalência mundial de manifestações clínicas sugestivas de depressão variou de 11\% a 40\%, conforme diversas variáveis verificadas. Conclusão: A prevalência de manifestações clínicas sugestivas de depressão encontrada para os portadores de doença falciforme é superior à prevalência de depressão descrita na população geral. Desse modo, é de suma importância o acompanhamento multidisciplinar para essas pessoas, com enfoque na saúde mental.

PALAVRAS-CHAVE

Doença falciforme, depressão, prevalência, transtorno depressivo maior. 


\section{INTRODUTION}

Sickle cell disease is a chronic and incurable group of hemolytic anemias resulted from a mutation in the gene that encodes the $\beta$ chain of hemoglobin, and an anomalous hemoglobin, $S$, is formed ${ }^{1-4}$. Such alteration is characterized by the replacement of the glutamic acid by valine ${ }^{1,3}$. Thus, when subjected to stressful situations, it undergoes a process of polymerization and takes a sickle format ${ }^{5-7}$. This characteristic leads to inadequate microcirculation, obstruction of capillary blood flow and hemolysis associated with a chronic inflammatory process ${ }^{5-7}$. This gene can be homozygous, leading to sickle cell anemia, or combined with another hemoglobinopathies such as $H b C, D, E$ and $\beta$-thalassemia, featuring a diverse clinical spectrum?. Therefore, patients experience several clinical events throughout their life, which are acute or chronic, generating a social and personal impact ${ }^{1,5}$.

It is one of the most common genetic diseases worldwide, mainly in the African continent, where the prevalence can reach $25 \%$ of the population in some countries ${ }^{4}$. In Brazil, the state of Bahia has a greater number of live births with sickle cell disease in the country, one in every $650^{8}$.

A patient with sickle cell anemia often needs hospitalization due to acute events, such as pain, priapism, stroke, acute chest syndrome, propensity to develop diseases, splenic sequestration, cholecystitis, among others ${ }^{5,9}$.

In order to address this problem, special attention should be directed to the mental health of these patients. The appearance of depressive symptoms is frequent due to chronicity and suffering inherent to the pathology, which can compromise the prognosis ${ }^{10,11}$.

Major depressive disorder is a mood disorder characterized by a range of signs and symptoms ${ }^{12}$. Among them are profound sadness, apathy, irritability, loss of interest, motor delay or agitation, suicidal ideation, and somatic complaints, especially insomnia, fatigue and anorexia stand out $^{12}$. Thus, a depressive patient has great suffering level and several functional impairments ${ }^{12,13}$. The diagnosis of major depressive disorder is clinical'12,14. Although globally validated scales contribute to the diagnosis, them alone do not define it ${ }^{14}$. However, several studies assess clinical manifestations suggestive of major depressive disorder only through scales ${ }^{14}$. Therefore, the prevalence of depression is often estimated based on the scores of these scales, even without systematic psychiatric evaluation ${ }^{14}$.

In general, patients with chronic illness have several limitations that end up affecting the entire social sphere of adult life, and are more likely to develop depression compared to the healthy population ${ }^{15}$. Thus, special attention should be paid to patients with sickle cell anemia, as they have risk factors for depression: a severe, painful and chronic disease ${ }^{10,13}$. Unfortunately, there is a lack of studies regarding this subject.
Given the above, this study aims to contribute to the current knowledge about the prevalence of clinical manifestations suggestive of depression in patients with sickle cell disease worldwide through a systematic review of the literature.

\section{METHODS}

A systematic literature review was performed, registered in the PROSPERO (Inter-national Prospective Register of Systematic Reviews) under registration number CRD42020200157. The guiding question was defined by the PVO model (participants, variables, outcomes) ${ }^{16}$.

\section{Eligibility criteria}

Studies that met the following inclusion criteria were considered eligible: cross-sectional studies that assessed the prevalence of major depressive disorder in patients with sickle cell disease, written in English or Portuguese and published in the last 10 years. Studies that did not use a validated instrument for the identification of major depressive disorder, incomplete publications or restricted to abstracts or posters, those that did not comply with ethical aspects or those that were duplicated were excluded.

\section{Information sources}

The electronic databases PubMed ${ }^{\circledR}$, LILACS and SciELO were used, assessed up from August 15t, 2020 to August 5 ${ }^{\text {th }}, 2020$.

\section{Search}

The research was carried out in the databases described, with the guiding question structured in the PVO model, using the descriptors "sickle cell disease", "depressive disorder", "sickle cell anemia" and "depression". All Entry Terms of "sickle cell disease" and "depressive disorder" and the operators "AND" and "OR" were also used.

\section{PubMed ${ }^{\circ}$ Search Strategy}

The following Mesh Terms were included in PubMed ${ }^{\circ}$ Search Strategy: sickle cell disease, sickle cell anemia, hemoglobin's disease, depressive disorder, endogenous depression, depressive syndromes, neurotic depression, unipolar depression, melancholia.

\section{Selection of studies}

The selection of articles was carried out in two stages and by two independent researchers. In the first stage, each researcher performed an initial screening from the titles and abstracts of the studies selected according to the inclusion criteria to identify potentially relevant studies. In the second stage, all articles classified as potentially relevant were retrieved for complete analysis of the text, based on 
the inclusion and exclusion criteria. Disagreements between researchers were solved by consensus.

The steps in the process of identifying and selecting studies are illustrated by means of a diagram in accordance with the PRISMA recommendation (Preferred reporting items for systematic reviews and meta-analyzes) ${ }^{17}$.

\section{Summary of results}

The data from the records included in this systematic review were extracted on a form and the information was summarized in a table, highlighting the prevalence ratio, the age group of the participants, year of publication, the location of each study, sample size, instrument used to assess depression and its cutoff point. The first author's last name and year of publication were used to identify each study.

\section{Quality assessment of included studies}

All included studies were submitted to a quality assessment through the Joanna Briggs Institute's critical appraisal checklist for analytical cross-sectional studies ${ }^{18}$. The same system for selecting the study was used.

The instrument consists of eight topics that assess the inclusion criteria, detail of the sample and research scenario, instrument for assessing health status and outcome, confounding factors and statistical analysis. "2 points" were defined for the criteria answered with "yes", "1 point" for "did not make it clear" and 0 for "no" or "not applicable". The higher the score obtained, the better the article quality, with 16 being the maximum score, according to this definition. Due to the low risk of bias, $70 \%$ was assigned as a cutoff point for quality. Thus, articles with a score lower than 11 were excluded from the review.

\section{RESULTS}

\section{Study selection}

The search strategy returned an equivalent of 42 titles (four duplicates), 22 studies were excluded after careful analysis of the title and abstract. The full text of the remaining 16 articles was evaluated, of which nine were identified and included, for responding to the question proposed in this systematic review. In total, 29 studies were excluded, 12 for not being related to the topic, 10 for not being cross-sectional, one for not using a valid instrument to screen for major depressive disorder and, finally, six for not describing the prevalence of depression in patients with sickle cell disease. This information was synthesized through a flowchart as shown in figure 1.

\section{Characteristics of included studies}

The data extracted from the nine records included in the present review are shown in table 1. Variations were observed regarding the instrument used to assess depression and the cutoff point chosen for the diagnosis. Thus, variations were also observed between the prevalence of depression in patients with sickle cell disease presented by each study.

The nine articles included in this review were carried out between the years 2011 and 2020 and add up to a total of 1,269 participants from different age groups; with four out of nine studies involving children. Most of the work was carried out in the United States (USA), three were carried out in Brazil and one in Nigeria.

In the quality assessment, most records $(44.4 \% / \mathrm{N}=03)$ scored 15 , because they did not make clear the strategies for dealing with confounding factors ${ }^{19-22}$. Three studies had a maximum score 10,23,24. And, two had scores equal to 1125,26. These two articles did not make clear the confounding factors and, consequently, the strategies to deal with them. These data are also summarized in table 1.
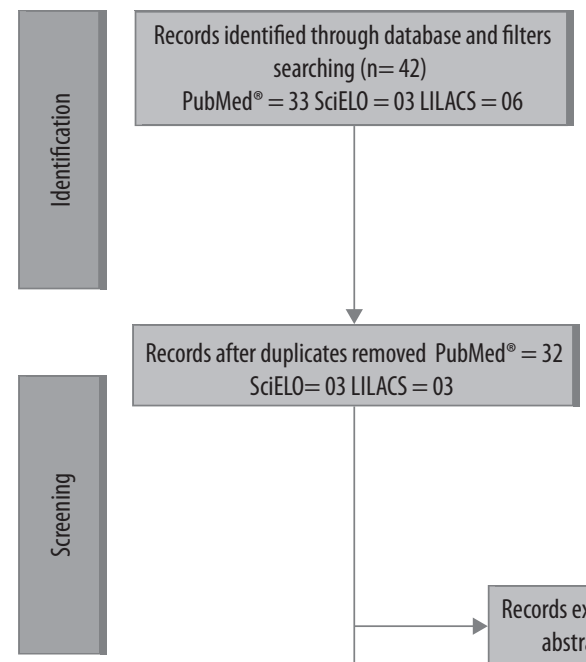
SCIELO $=03$ LILACS $=03$
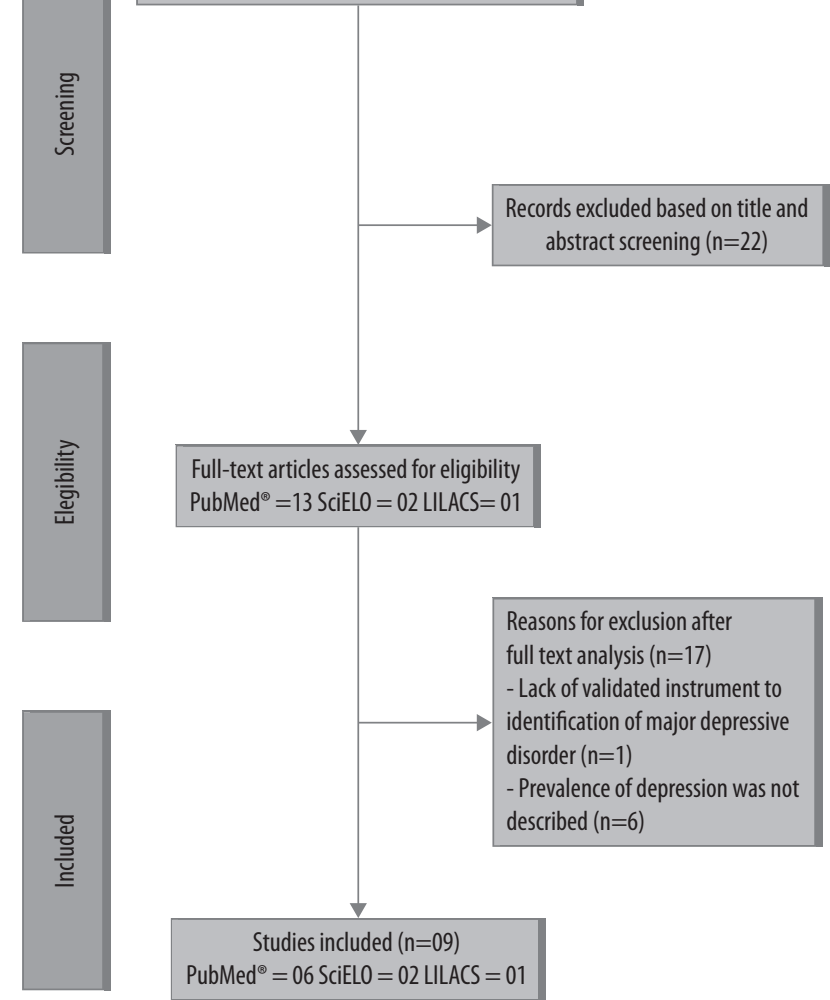

Figure 1. Flowchart referring to the selection of articles searched in the PubMed ${ }^{\oplus}$, LILACS and SciELO databases, in August 2020, according to the established eligibility criteria. 
Table 1. Description of the nine studies selected in August 2020 for the present systematic review

\begin{tabular}{|c|c|c|c|c|c|c|}
\hline $\begin{array}{l}\text { Author and } \\
\text { year of } \\
\text { publication }\end{array}$ & Location & Sample size & Age group & $\begin{array}{l}\text { Instrument used to } \\
\text { diagnose major } \\
\text { depressive disorder }\end{array}$ & Prevalence & Quality Score \\
\hline Benton, $2011^{25}$ & Philadelphia, USA & 40 & $\begin{array}{c}\text { From } 12 \text { to } 19 \text { years } \\
\text { old }\end{array}$ & ChIPS & $12.5 \%$ & 11 \\
\hline Vilela, $2012^{19}$ & Alagoas, Brazil & 25 & +20 years old & $\begin{array}{c}\text { BDI } \\
\text { Cutoff point: }>20\end{array}$ & $16 \%$ & 15 \\
\hline Mastandréa, $2015^{20}$ & São Paulo, Brazil & 110 & $\begin{array}{c}\text { From } 18 \text { to } 67 \text { years } \\
\text { old }\end{array}$ & $\begin{array}{c}\text { PHQ-9 } \\
\text { Cutoff point: } \geq 10\end{array}$ & $30 \%$ & 15 \\
\hline Robbins, $2020^{23}$ & USA & 336 & +18 years old & $\begin{array}{c}\text { PHQ-9 } \\
\text { Cutoff point: } \geq 10\end{array}$ & $28 \%$ & 16 \\
\hline Barreto, $2011^{10}$ & Sergipe, Brazil & 76 & $\begin{array}{l}\text { From } 7 \text { to } 17 \text { years } \\
\text { old }\end{array}$ & $\begin{array}{c}\text { CDI } \\
\text { Cutoff point: } \geq 13\end{array}$ & $34.2 \%$ & 16 \\
\hline Raji, $2016^{22}$ & South of Nigeria & 205 & $\begin{array}{c}\text { From } 18 \text { to } 65 \text { years } \\
\text { old }\end{array}$ & $\begin{array}{c}\text { MINI Plus - } \\
\text { Depression module }\end{array}$ & $16.6 \%$ & 15 \\
\hline $\begin{array}{l}\text { Goldstein-Leever, } \\
2018^{24}\end{array}$ & Ohio, USA & 100 & $\begin{array}{l}\text { From } 8 \text { to } 18 \text { years } \\
\text { old }\end{array}$ & $\begin{array}{l}\text { CDI-II } \\
\text { Cutoff point: } \geq 14\end{array}$ & $27 \%$ & 16 \\
\hline $\begin{array}{l}\text { Moscou-Jackson, } \\
2016^{26}\end{array}$ & $\begin{array}{l}\text { Middle Atlantic of } \\
\text { USA }\end{array}$ & 263 & + 18 years old & $\begin{array}{c}\text { CESD-10 } \\
\text { Cutoff point: } \geq 10\end{array}$ & $40 \%$ & 11 \\
\hline Valrie, $2020^{21}$ & Southeastern of USA & 114 & $\begin{array}{c}\text { From } 8 \text { to } 17 \text { years } \\
\text { old }\end{array}$ & $\begin{array}{c}\text { BASC-2 } \\
\text { Cutoff point: } \geq 60\end{array}$ & $11 \%$ & 15 \\
\hline
\end{tabular}

ChIPS: Children's Interview for Psychiatric Syndromes child; BDI: Beck Depression Inventory; PHQ-9: The Patient Health Questionnaire-9; CDI: Children's Depression Inventory; CESD-10: Center for Epidemiologic Studies Depression Scale; BASC-2: Behavior Assessment System for Children.

\section{Prevalence of clinical manifestations suggestive of major depressive disorder}

Among the nine studies, eight used cluster sampling and carried out the research in patients with sickle cell disease who were being followed up on an outpatient basis in a particular hematology center in the region studied ${ }^{10,19-25}$. Only one study took its sample from a previous prospective cohort study ${ }^{26}$.

It is important to note that most studies used data from medical records to confirm the diagnosis of sickle cell disease and its genotype (S $\beta$ thalassemia, SC and SS) 20,21,23-25. Only two used hemoglobin electrophoresis ${ }^{19,22}$. And two others did not describe how the diagnosis was established, nor the genotype of the participants ${ }^{10,26}$.

Seven different instruments were used to screen for major depressive disorder, with different cutoff points, and The Patient Health Questionnaire-9 (PHQ-9) was the most used instrument. The worldwide prevalence of clinical manifestations suggestive of depression varied from $11 \%$ to $40 \%$, according to the instrument, cutoff point, age group, year of publication and country of origin.

In all studies included in this review, the majority of the patients was black. In seven of these, there was a predominance of females ${ }^{19-24,26}$. However, none of the articles established statistical significance between the development of depression and the participant's gender. The same occurred with the genotype, which prevailed HbSS in all seven studies that described this variable ${ }^{19-24,26}$.
Regarding education, income and unemployment, an article established statistical significance between these variables and the development of depression ${ }^{22}$. However, of those who presented the participants education, only one of them had the majority of the patients completed high school23. As for income and unemployment, only one study reported that the majority of its population was employed ${ }^{19}$.

In the USA, five studies were carried out, from which three focused on children and adolescents. The less recent was held in Philadelphia, published in 2011 and included 40 teenagers, between 12 and 18 years old ${ }^{25}$. This study used Children's Interview for Psychiatric Syndromes child (ChIPS) and described a 12\% prevalence of depression, however, it did not inform the cutoff point used to consider the diagnosis of depression ${ }^{25}$. In 2018, another article was published in this country on the topic, which was set in Ohio with 100 children and adolescents between 8 and 18 years old ${ }^{24}$. The Children's Depression Inventory II (CDI-II) was used and the cutoff point was 14, with $27 \%$ being the prevalence found for major depressive disorder ${ }^{24}$. The last study carried out in the USA with children and adolescents on this topic was published in 2020 and involved 114 patients with sickle cell disease aged between 8 and 17 years old ${ }^{21}$. In this research, the instrument used to screen for major depressive disorder was the Behavior Assessment System for Children (BAS-2), whose cutoff point was 60 and the prevalence found was $11 \%$. It should be noted that this prevalence of $11 \%$ included both those who scored for depression and those classified as at risk for depression ${ }^{21}$. 
Regarding the American adult population, two articles have been published on this topic in the country. The most recent one was published in 2020 and studied 336 people with sickle cell disease. This study used PHQ-9 to screen for depression, whose cutoff point was 10, and described a 28\% prevalence of major depressive disorder in this population ${ }^{21}$. In 2016, an article was published in the USA about insomnia and its predictors in patients with sickle cell disease. Such research, conducted with 263 African-American adults, suggested depression as a risk factor for insomnia in this population and described the of major depressive disorder ${ }^{26}$. For this purpose, the Center for Epidemiologic Studies Depression Scale (CESD-10) questionnaire was used, with a cutoff point greater than or equal to 10, and the prevalence of $40 \%$ of major depressive disorder was described ${ }^{26}$.

In Brazil, three studies have been carried out on this topic, only one in the youth population. Among those performed in the adult Brazilian population, the most recent was published in 2015 and performed in São Paulo ${ }^{20}$, with 110 patients suffering from sickle cell disease in the age group from 18 to 67 years old. The PHQ-9 was used with a cutoff point of 10 to consider the diagnosis of depression, finding a prevalence of $28 \% \%^{20}$. Another study, carried out in Alagoas and published in 2012, where only 25 adults (over 20 years old and mostly male, $73.3 \%$ ) participated, $16 \%$ had criteria for major depression ${ }^{19}$. The instrument used was the Beck Depression Inventory (BDI) and the established cutoff point was $20^{19}$.

The only Brazilian study about the prevalence of clinical manifestations suggestive of depression in children and adolescents with sickle cell disease included in this review was published in 2011 and carried out in Sergipe. It assessed, through the ICD with a cutoff point greater than or equal to 13, 76 children and adolescents, between 7 and 17 years old, mostly boys (53.4\%), and found that $34.2 \%$ had depressive symptoms ${ }^{10}$.

Finally, the only Nigerian article included in the review was published in 2016 and studied 205 adults, aged 18 to 65 years, of which $16.6 \%$ were identified with major depressive disorder according to the instrument used, the MINI Plus - Depression module ${ }^{22}$. However, the cutoff point used to consider the diagnosis of depression was not informed ${ }^{22}$.

\section{DISCUSSION}

The present review shows a high worldwide prevalence of clinical manifestations suggestive of depression in patients with sickle cell disease. Several factors can be related to this observation, such as, for example, unemployment, low level of education, poverty, painful crises and use of analgesics ${ }^{22}$. Corroborating this fact, one of the studies included in this review demonstrated that the individual's health condition and its complications became an obstacle to getting good paying jobs ${ }^{19}$. Thus, a vicious cycle of poverty, low quality of life and depression is shown.

The high prevalence of clinical manifestations suggestive of depression in patients with sickle cell disease is evident in childhood, as shown by research on children and adolescents $10,21,24,25$. It is higher than the prevalence in the general population in this age group ${ }^{24,25}$. This is an extremely worrying fact, since depression is related to worse adherence to clinical treatment and low likelihood of changes in lifestyle ${ }^{25}$. In addition, depression in this population was also associated with low self-reported interpersonal skills, predisposing to social isolation ${ }^{21}$.

Unfortunately, none of the nine selected articles assessed both minors and adults at the same time. To address this issue, considering only the studies carried out in the USA for a fairer comparison, where three of them were conducted

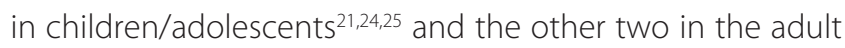
population ${ }^{23,26}$, a tendency to a higher prevalence as age increases is suggested. Thus, further research on this matter is required to corroborate that statement.

When analyzing the prevalence of clinical manifestations suggestive of depression in patients with sickle cell disease in Brazilian studies, it is interesting to note that the one which described the lowest prevalence was also the one where the majority of the sample population was employed. In addition, this study had the smallest sample size ${ }^{19}$. This fact, as already discussed, is, like shown, related to the lower development of depression ${ }^{19,22}$.

It is also clear from the records included in this review that, despite all studies showing a high prevalence of symptoms suggestive of depression, it is clear to see a wide variation. As already mentioned, several factors can be related to this, mainly, the instrument used to screen for depression and the cutoff point. It was observed that the higher the cutoff point for identifying depression, the lower the prevalence. However, it is not possible to state that this is the only factor responsible for the variation. In addition to the variables already mentioned, cultural factors, treatment effectiveness, marital status and pain severity were also variables that interfere with quality of life and thus can be related to depression 19,22,24. Thus, the characteristics of the sampled population interfere with the prevalence of depression described.

In the general population, women are more likely to develop depression ${ }^{27}$. As seven of the selected articles are predominantly female among the participants, the results obtained could have been overestimated ${ }^{19-24,26}$. However, all of the four articles that established a comparison of the prevalence of depression between men and women stated no statistical difference in the results ${ }^{10,22-24}$. Thus, it is recommended that new studies are carried out to assess a possible difference in the prevalence of depression between 
genders in patients with sickle cell disease. Despite this issue, the results obtained should not be disregarded, as they reflect a serious health problem. According to the World Health Organization (WHO), the prevalence of global depression is $4.4 \%{ }^{27}$, which is much lower than the prevalence of clinical manifestations suggestive of depression found for patients with sickle cell disease in this review.

It is also essential to highlight the limitations of this review. Regarding the method of diagnosis of sickle cell disease carried out in the included studies, as mentioned above, most used data from medical records $20,21,23-25$, while only two used hemoglobin electrophoresis ${ }^{19,22}$ and two others did not describe how the diagnosis was established, nor the genotype of the participants ${ }^{10,26}$. Thus, it is necessary to emphasize that the lack of detailed psychiatric evaluation is a limitation of this review, since the final diagnosis of depression can only be reached through clinical interview. The failure to establish the diagnostic method, as well as its non-confirmation, can weaken the aforementioned records. In addition, the absence of supplementary search and other databases for additional studies, as well as the inclusion of articles published only in English or Portuguese are limitations that may have contributed to the fact that most of the studies found are from the United States and Brazil|10,19-21,23-26. The heterogeneity between the major depressive disorder assessment instruments is also a limitation of this study.

\section{CONCLUSION}

After a systematic review of the literature on the prevalence of clinical manifestations suggestive of depression in patients with sickle cell disease, it is possible to infer, in comparison to data assessed by $\mathrm{WHO}$, that these patients have a higher prevalence of depression compared to the rest of the population. However, it is important to emphasize that the instruments used to assess depression in the reviewed studies are screening tools, and the definite diagnosis requires a psychological assessment carried out by a qualified professional. Despite this, in the original articles, the authors used predefined cutoff points to consider the diagnosis of depression and its prevalence could be estimated. Thus, the results of this study alert for the high prevalence of clinical manifestations suggestive of depression in sickle cell patients. It is of great importance that professionals are attentive to the variables that may predispose this condition, such as severe pain, lack of emotional support, lowlevel of education and, consequently, unemployment. Therefore, multidisciplinary follow-up for patients with sickle cell disease and monitoring of school performance is extremely important, as dropout can lead to social isolation and unemployment conditions in the future, both related to the development of depression.
In addition, there was a shortage of literature on the subject, especially in areas where there is a high prevalence of depression, such as Nigeria, where only one study was assessed, and in Brazil, mainly in the state of Bahia, which has the highest number of live births patients with sickle cell disease in the country ${ }^{8}$, but there is no publication in the databases researched in this review on the topic.

\section{INDIVIDUAL CONTRIBUTIONS}

Amanda Gabrielle Santos Leite and Liz Freitas de Sá Oliveira - Conceptualization of this study, as well as data collection, analysis and investigation, methodology and draft's execution.

Isa Menezes Lyra and Ricardo Coutinho Fortes Supervision, administration, methodology, review, writing and editing of the project.

\section{CONFLICTS OF INTEREST}

The authors declare no conflicts of interest and no financial support.

\section{ACKNOWLEDGMENTS}

We thank Dr. Carla Hilário da Cunha Daltro for all the support.

\section{REFERENCES}

1. Menezes ASOP, Len CA, Hilário MOE, Terreri MTRA, Braga JAP. Qualidade de vida em portadores de doença falciforme. Rev Paul Pediatr. 2013;31(1):24-9.

2. Cançado RD, Jesus JA. A doença falciforme no Brasil. Rev Bras Hematol Hemoter. 2007;29(3):203-6.

3. Steinberg M. Pathophysiologically based drug treatment of sickle cell disease. Trends Pharmacol Sci . 2006;27(4):204-10.

4. Brasil. Ministério da Saúde. Secretaria de Atenção à Saúde. Departamento de Atenção Especializada. Doença Falciforme: Diretrizes Básicas da Linha de Cuidado. v. 1, Brasilia, DF; 2015. 84p.

5. Zago MA, Pinto ACS. Fisiopatologia das doenças falciformes: da mutação genética à insuficiência de múltiplos órgãos. Rev Bras Hematol Hemoter. 2007;29(3):207-14.

6. Nuzzo DVP Di, Fonseca SF. Anemia falciforme e infecçōes. J Pediatr (Rio J). 2004;80(5):347-54.

7. Felix AA, Souza HM, Ribeiro SBF. Aspectos epidemiológicos e sociais da doença falciforme. Rev Bras Hematol Hemoter. 2010;32(3):203-8.

8. Brasil. Ministério da Saúde do Brasil. Secretaria de Atenção à Saúde. Departamento de Atenção Hospitalar e de Urgência. Doença Falciforme: Atenção integral à saúde das mulheres. 1a ed. Brasília, DF; 2015. 12p.

9. De Baum MR, Frei-Jones M, Vichinsky E. Doença falciforme. In: Kliegman R, Stanton B, Schor N, Geme Jws, Behrman R. Nelson: Tratado de Pediatria. 19a ed. Rio de Janeiro: Elsevier; 2014. 4.992p

10. Barreto FJN, Cipolotti R. Sintomas depressivos em crianças e adolescentes com anemia falciforme. J Bras Psiquiatr. 2011;60(4):277-83. 
11. Alao A, Dewan M, Jindal S, Effron M. Psychopathology in sickle cell disease. West Afr J Med. 2003;23(4):334-7.

12. Cavalcante FE, Galvan AL. Depressão numa contextualização contemporânea. Aletheia. 2006; $1(24): 127-35$.

13. Teng CT, Humes EC, Demetrio FN. Depressão e comorbidades clínicas. Rev Psiq Clín. 2005;32(3):149-59.

14. Baptista MN, Borges L. Revisão integrativa de instrumentos de depressão em crianças/ adolescentes e adultos na população brasileira. Aval Piscol. 2016 15(n.esp.):19-32.

15. Boing AF, Melo GR, Boing AC, Moretti-Pires RO, Peres KG, Peres MA. Associação entre depressão e doenças crônicas: estudo populacional. Rev Saude Publica. 2012;46(4):617-23.

16. Biruel EP, Pinto RR. Bibliotecário um profissional a serviço da pesquisa. In: Anais, XXIV Congresso Brasileiro de Biblioteconomia, Documentação e Ciência da Informação. 2011.

17. Moher D, Liberati A, Tetzlaff J, Altman D. Principais itens para relatar revisões sistemáticas e metanálises: a recomendação PRISMA. Epidemiol Serv Saúde. 2015;24(2):335-42.

18. Moola S, Munn Z, Tufanaru C, Aromataris E, Sears K, Sfetcu R, et al. Chapter 7: Systematic reviews of etiology and risk. In: Aromataris E, editor. Joanna Briggs Institute Reviewer's Manual. North Adelaide: The Joanna Briggs Institute; 2017. p. 6.

19. Vilela RQB, Cavalcante JC, Cavalcante BF, Araújo DL, Lôbo MM, Nunes FAT. Quality of life of individuals with sickle cell disease followed at referral centers in Alagoas, Brazil. Rev Bras Hematol Hemoter. 2012;34(6):442-6.
20. Mastandréa ÉB, Lucchesi F, Kitayama MMG, Figueiredo MS, de Albuquerque Citero V. A relação entre genótipo, sintomas psiquiátricos e qualidade de vida em pacientes adultos com doença falciforme em São Paulo, Brasil: Um estudo transversal. Sao Paulo Med J. 2015;133(5):421-7.

21. Valrie C, Floyd A, Sisler I, Redding-Lallinger R, Fuh B. Depression and anxiety as moderators of the pain-social functioning relationship in youth with sickle cell disease. J Pain Res. 2020;13:729-36

22. Raji SO, Lawani A0, James BO. Prevalence and correlates of major depression among Nigerian adults with sickle cell disease. Int J Psychiatry Med. 2016;51(5):456-66.

23. Robbins MA, Carroll CP, North CS. Psychological symptom screening in an adult sickle cell disease clinic and predictors of treatment follow up. Psychol Heal Med. 2020;00(00):1-9.

24. Goldstein-Leever A, Cohen LL, Dampier C, Sil S. Parent pain catastrophizing predicts child depressive symptoms in youth with sickle cell disease. Pediatr Blood Cancer. 2018;65(7).

25. Benton TD, Boyd R, Ifeagwu J, Feldtmose E, Smith-Whitley K. Psychiatric diagnosis in adolescents with sickle cell disease: A preliminary report. Curr Psychiatry Rep. 2011;13(2):111-5.

26. Moscou-Jackson G, Allen J, Kozachik S, Smith MT, Budhathoki C, Haywood C. Acute Pain and Depressive Symptoms: Independent Predictors of Insomnia Symptoms among Adults with Sickle Cell Disease. Pain Manag Nurs. 2016;17(1):38-46.

27. World Health Organization. Depression and Other Common Mental Disorders - Global Health Estimates. Geneva: WHO; 2017. 8p. 